\title{
CHANGES IN THE IT OUTSOURCING PRACTICE: A CLIENT-VENDOR VIEWPOINT
}

\author{
Mohammed H. A. Tafti, Hofstra University, mohammed.h.tafti@hofstra.edu
}

\begin{abstract}
IT outsourcing has substantially changed from the way it was practiced some three decades ago. Review of the literature indicates that as clients and vendors have gained more experience, their relationship characteristics have noticeably changed, and the landscape of modern IT outsourcing industry has significantly transformed. For example, IT outsourcing has evolved beyond arms-length transaction, and has more recently encompassed a wide range of high-level systems and services that are provided through collaboration and strategic alliances. The purpose of this paper is to present a framework for analysis of the changing characteristics of IT outsourcing clients, vendors, and their relationships. Research and practical implications are discussed.
\end{abstract}

Keywords: IT Outsourcing, Client-Vendor Relationship, Strategic Alliance, Globalization

\section{INTRODUCTION}

IT outsourcing has become a main component of the souring strategy of modern enterprises. In the early stages of IT outsourcing, client-vendor relationships were predominantly characterized as arms-length transactions. IT outsourcing has since evolved beyond handing over routine applications and coding functions to vendors, and has more recently encompassed a wide range of high-level systems and services that are provided through collaboration and strategic alliances. A major reason organizations outsourced their IT activities in the past was to reduce their high cost of application development $[2,31]$. As high as $80 \%$ of the respondents in a previously conducted survey cited the desire to reduce IT costs as a key reason for outsourcing all or part of their IT operations [27]. Another common reason for resorting to IT outsourcing has been a firm's desire to focus its resources on those activities that are considered its strengths, often referred to as core competencies [2, 28].

However, considerable shifts in role and significance of these incentives and subsequent changes in various IT outsourcing attributes have created a new landscape of contemporary IT outsourcing practice. For example, among all reasons to outsource the one that has emerged as the prime reason in recent years is to gain competitive advantage through partnership by sharing information and knowledge [54]. While IT outsourcing practices during late 80 's and 90's have predominantly encompassed routine, transaction-based type activities such as program coding and help desk activities, a greater portion of recent outsourcing contracts are on higher-level, knowledgebased IT activities such as business processes and ERP.

Besides the shift from cost-justification, there exist a host of other interesting changes in the trends of IT outsourcing. For example, as organizations have gained more experience in outsourcing their IT activities and as outsourcing companies became more mature in offering IT services, new types of outsourcing deals and contracts have emerged [1]. Furthermore, the changing trend in client-vendor relationship has deemed a new set of IT-related skills and activities such as knowledge management and relationship management necessary. What specific changes in characteristics of clients, vendors, and client-vendor relationships have occurred during the relatively short history of IT outsourcing? This paper attempts to shed some light on this question by presenting an IT outsourcing client-vendor framework that can explain the changing landscape of IT outsourcing. Specific attributes of clients, vendors, and their relationships are explored, and a general framework for the study of changes in the IT outsourcing landscape from client-vendor viewpoint is presented. 


\section{Issues in Information Systems}

Volume 13, Issue 2, pp. 146-154, 2012

\section{ATTRIBUTES OF IT OUTSOURCING CLIENTS, VENDORS, AND THEIR RELATIONSHIPS}

An expedient way to explore the IT outsourcing landscape is to study the major players and their relationship in this playing field. Review of outsourcing literature indicates a number of noticeable shifts in IT outsourcing attributes as related to clients, vendors, and client-vendor relationships. It appears that although most, if not all, of factors that have influenced the decision to outsource in the 80's and 90's may still be valid, there is a clear shift in the order of significance of these factors. Also, new attributes such as knowledge-sharing and strategic alliance are gaining significant role in shaping the IT outsourcing landscape. Following presents a discussion of three categories of changes as related to clients, vendors, and client-vendor relationship.

\section{IT Outsourcing Clients}

Major changes that have occurred in the IT outsourcing arena are largely due to a considerable change in various aspects of clients in terms of their motivation, strategy, tactics, and experience. This section presents an overview of the changing attributes of IT outsourcing clients.

A Shift from Cost-Reduction Incentive to Value Generating: Predominant incentive for companies to engage in IT outsourcing has initially been cost efficiency [27]. Development costs have often been cited in the literature as the major factor that has significantly influenced global outsourcing particularly in the 90's [12, 13, 20]. For example, a U.S. based ASP with a ratio of 25 IT workers on-site to 75 workers in India was expected to pay a blended hourly labor rate of about $\$ 37$, compared with an average rate of $\$ 75$ to $\$ 100$ for U.S. teams.

However, the cost structure has changed considerably, mostly due to rapidly increased demand of qualified technical workers overseas. While the prime driver of earlier outsourcing practices has been the need to control IT costs, a main incentive for many recent outsourcing agreements has shifted towards the need to leverage the investment in IT for creating business value such as improved quality, increased speed to market, and enhanced customer service [4]. Recent, management decisions to outsource IT functions are justified more on the basis of where the highest overall value can be realized than merely where the cost is cheapest [18].

SME Participation: Major players in the IT outsourcing practice in the beginning included almost exclusively large organizations such as Kodak, Microsoft, and General Motors. The role of small and medium-size enterprise (SME), however, is becoming more and more significant in the contemporary IT outsourcing market. According to Gartner, approximately 90 percent of all new businesses in the USA are SMEs and the trend is toward their increasing use of outsourcing [34]. The advent of the internet and open systems has brought about several options for SMEs in sourcing IT solutions which were not available or affordable for them until recently [11]. Recent advancements in communications and the Internet technology have opened new windows of opportunities for many SMEs in IT sourcing strategies including the supply chain management and ERP [4].

New Players in the Playing Field: Outsourcing IT functions are not exclusively practiced by business organizations any more [43]. Government organizations, at both federal and state level are increasingly engaged in IT outsourcing as well. It has been estimated that government spending on outsourced IT functions will increase by an annual compound rate of 8.3 percent from $\$ 11.7$ billion in 2004 to $\$ 17.4$ billion in 2009 [47]. Government participation in IT outsourcing has increasingly gained momentum in recent years. For example, In 2006 San Diego officials approved a \$667 million IT outsourcing contract, and Virginia officials approved a 10-year, \$2 billion agreement with Northrop Grumman Information Technology to manage their IT operations [51].

Gain in IT Outsourcing Experience: Lessons learned from previous IT outsourcing practices have led many organizations to a higher-level and more settled outsourcing arrangements and contracts. Prior outsourcing experience has enabled these organizations, as informed buyers, to better analyze the external IT market and select the right sourcing strategy that meet their business needs and solve their IT issues [35]. Additionally, the 


\section{Issues in Information Systems}

Volume 13, Issue 2, pp. 146-154, 2012

organizations that have gained more experience are in a better position to assess various risks involved in IT outsourcing practices [50].

Diversity of Outsourced tasks: The majority of the tasks that have been outsourced in the past were structured and straight-forward activities that involved programming. In other words, these tasks were routine and could be easily defined and codified [33]. Skills that were outsourced did not require close interaction between the client and service supplier, and sharing of a tacit knowledge base [5]. As the significance of cost factor diminished due to the changing outsourcing market, and organizations gained a higher level of maturity in outsourcing practices, more knowledge-oriented and less structured tasks are being outsourced. Contemporary IT outsourcing practice encompasses a variety of tasks including program coding, business processes, complex application development, and ERP.

Due to the changes in the above attributes (among others), IT outsourcing has evolved significantly and continues to reshape its landscape as various characteristics of the outsourcing clients evolve. Table one summarizes the attributes discussed in this section.

Table 1: Changes in Client Attributes

\begin{tabular}{|l|l|l|}
\hline \multicolumn{1}{|c|}{ Attribute } & \multicolumn{1}{|c|}{ Description } & \multicolumn{1}{|c|}{ Reference } \\
\hline Value Orientation & $\begin{array}{l}\text { Initial focus on reducing cost has shifted to the need } \\
\text { to leverage the investment in IT outsourcing for } \\
\text { business value such as improved quality, increased } \\
\text { speed to market, strategic alliance, and enhanced } \\
\text { customer value. }\end{array}$ & $\begin{array}{l}\text { Dibbern, Winkler, and Armin, } \\
\text { 2008; Cederlund et. al., 2007 } \\
\text { Fantasia, 2000 } \\
\text { Greenemeier, 2000 } \\
\text { Gottschalk and Solli-Sæther, 2006 } \\
\text { Lacity and Willcocks, 1998 }\end{array}$ \\
\hline SME Participation & $\begin{array}{l}\text { Initial IT outsourcing that was limited to large } \\
\text { organizations has evolved to be a major sourcing } \\
\text { option for small and medium-size enterprise. }\end{array}$ & $\begin{array}{l}\text { Bryson and Sullivan, 2003 } \\
\text { DePompa, 2003 } \\
\text { Mears, 2006 }\end{array}$ \\
\hline $\begin{array}{l}\text { Public Sector as } \\
\text { New Player }\end{array}$ & $\begin{array}{l}\text { The public sector has gradually entered in the IT } \\
\text { outsourcing arena. Government, at both federal and } \\
\text { state levels, has become a substantial, active player } \\
\text { in IT outsourcing. }\end{array}$ & $\begin{array}{l}\text { Schofield, 2008 } \\
\text { Soat, 2004 } \\
\text { Thibodeau, 2006 }\end{array}$ \\
\hline $\begin{array}{l}\text { Outsourcing } \\
\text { Experience }\end{array}$ & $\begin{array}{l}\text { Many organizations renew their existing IT } \\
\text { outsourcing contracts and/or sign new contracts, } \\
\text { gaining more experience in reducing various risks } \\
\text { associated with outsourcing. }\end{array}$ & $\begin{array}{l}\text { Peslak, 2012 } \\
\text { Tafti, 2005 }\end{array}$ \\
\hline Outsourced Tasks & $\begin{array}{l}\text { Contemporary IT outsourcing involves diverse tasks } \\
\text { involving more knowledge-oriented and higher-level } \\
\text { tasks such as ERP. }\end{array}$ & $\begin{array}{l}\text { Bullen et al., 2007 } \\
\text { McFarlan and Delacey, 2004 }\end{array}$ \\
\hline
\end{tabular}

\section{IT Outsourcing Vendors}

Vendor characteristics have also changed considerably during the past three decades contributing to emergence of a new landscape of IT outsourcing [39]. Globalization and diversity of outsourcing services and providers, increased competition, maturity of the industry, and host country support and initiatives are noticeable areas of vendor-related changes [38].

Globalization: Initial IT outsourcing contracts with national vendors such as IBM and EDS has gradually been complemented and/or replaced by outsourcing arrangements with vendors outside the United States. Sending the work overseas, called offshoring, has gained significant momentum by mid-90s due to the sudden rush to achieve Y2K compliance as well as the dot.com "bandwagon" phenomenon resulting in severe shortage of qualified programmers $[6,8,36]$. India has become a major player in IT outsourcing due to abundance of English-speaking, 


\section{Issues in Information Systems}

Volume 13, Issue 2, pp. 146-154, 2012

talented IT professionals, particularly computer programmers [10]. Most recently, the IT outsourcing market has become global with several major players including India, China, Russia, European and southern American countries among many others [14].

Diversity of Providers and Services: Recent advancements in computer and telecommunications technologies and in system development methodologies have led to many new sourcing options of IT functions. The rise of application service providers (ASPs), made possible by the Internet, has provided a great opportunity for a large number of companies to receive software and services remotely from a large variety of providers [3]. ASPs have capabilities of offering a wide variety of services from routine e-mail and electronic spreadsheet to e-commerce applications, ERP, and supply chain management systems [49]. A more recent service model called software as a service (SaaS) has emerged that offers more flexibility to the user organizations. SaaS vendors provide application modules to customers via the Internet. This model, which enables client organizations to access application functionalities that they need for a monthly or pay-per-use at considerably lower cost without any investment in hardware or software, is particularly a convenient sourcing option for SMEs [22].

Maturity of Outsourcing Industry: In the short history of IT outsourcing, the industry has emerged as a very competitive and highly established industry with professional associations, certification programs, and strong public relations media. The industry participants can collectively influence shaping the structure, strategy, magnitude, and direction of IT outsourcing [21]. The Outsourcing Institute is one of the major professional associations. Established in 1993, it "tracks and forecasts the rapid evolution of outsourcing while providing new services and programs to assist buyers and sellers of outsourcing services as well as industry influencers." (http://www.outsourcing.com). The institute serves as the industry catalyst, as hub for information exchange, and as a "go-to" place for collaboration. It provides free membership, conducts research, and provides publications and information on the outsourcing industry. The IT outsourcing industry is adequately established to provide practice guidelines and offer professional certifications [37]. Furthermore, there are various collective efforts to strengthen the industry's advocacy of various industry-related issues. For example, there is a recent initiative by a service firm to launch an "outsourcing bill-ofrights" covering issues such as transparency in the financial viability of an IT vendor; this helps to gain industry support in establishing standardized rules of engagement for clients and vendors in their IT outsourcing deals [25].

Vendor's Host Country Initiatives: Alongside industry-wide associations and professional organizations, closer interest and support of the vendor's host country government as well as international organizations has emerged to be substantial. For example, among major challenges for organizations engaged in IT outsourcing are protecting privacy of the clients and information security of the firm as well as safeguarding the firm's intellectual property [52]. There are steps being taken to legally, through various regulatory agencies, to establish favorable regulations and law enforcement procedures. For example, in the fall of 2006 the Indian Cabinet cleared the amendment to the "IT Act 2000" that paved the way to subsequently introduce a Bill addressing security and privacy concerns [40]. Also, the World Trade Organization has added regulatory procedures on intellectual property (Trade-Related Aspects of Intellectual Property Rights) that must be adhered by all member countries [9].

Table 2: Changes in Vendor Attributes

\begin{tabular}{|c|c|c|}
\hline Attribute & Description & Reference \\
\hline $\begin{array}{l}\text { Globalized IT } \\
\text { Outsourcing }\end{array}$ & $\begin{array}{l}\text { Sending various IT functions oversees, called } \\
\text { offshoring, has become a commonplace practice. } \\
\text { Most recently, the IT outsourcing market has } \\
\text { become global with several major players including } \\
\text { India, China, Russia, European and southern } \\
\text { American countries among many others. }\end{array}$ & $\begin{array}{l}\text { Carmel and Nicholson, } 2005 \\
\text { Chu-Ping \& Guang-Jong, } 2010 \\
\text { Davies, } 2004 \\
\text { Friedman, } 2005\end{array}$ \\
\hline $\begin{array}{l}\text { Diversity of } \\
\text { Services and } \\
\text { Providers }\end{array}$ & $\begin{array}{l}\text { Contemporary IT outsourcing practice involves a } \\
\text { large variety of providers and services including } \\
\text { application service providers and software as } \\
\text { service. }\end{array}$ & $\begin{array}{l}\text { Borck, } 2000 \\
\text { Kenney, } 2007 \\
\text { Susarla, Barua, and Whinston, } \\
2003\end{array}$ \\
\hline
\end{tabular}




\section{Issues in Information Systems}

Volume 13, Issue 2, pp. 146-154, 2012

\begin{tabular}{|l|l|l|}
\hline $\begin{array}{l}\text { Maturity of } \\
\text { Outsourcing }\end{array}$ & $\begin{array}{l}\text { IT outsourcing has emerged as a profoundly } \\
\text { established industry with professional associations, } \\
\text { certification programs, and strong public relations } \\
\text { media. The industry participants can collectively } \\
\text { influence shaping the structure, strategy, magnitude, } \\
\text { and direction of IT outsourcing. }\end{array}$ & $\begin{array}{l}\text { Grimshaw and Miozzo, 2006 } \\
\text { Kolbasuk McGee, 2009 } \\
\text { Pratt, 2006 }\end{array}$ \\
\hline $\begin{array}{l}\text { Host Country } \\
\text { Initiatives }\end{array}$ & $\begin{array}{l}\text { Support of the vendor's host country government as } \\
\text { well as international organizations have emerged to } \\
\text { be substantial in protecting privacy and security } \\
\text { interests of the outsourcing clients. }\end{array}$ & $\begin{array}{l}\text { Das, 2008 } \\
\text { Rustad and Koenig 2007 }\end{array}$ \\
\hline
\end{tabular}

\section{IT Outsourcing Client-Vendor Relationships}

Since the inception of IT outsourcing in late 1980s when outsourcing clients and vendors would mostly deal at "arm's length", there have been considerable changes in client-vendor relationships. In the contemporary IT era the arm's length transaction model has been mostly replaced, or at least complemented, by strategic partnership model $[44,48]$. While there is still a need for signing an outsourcing contract, the terms and contents of more recent contracts are noticeably different from those of early 1990s. Clients and vendors are more open to sharing knowledge and confident, and well as competent, in joint collaboration in performing IT functions [16, 28].

Global Collaborative Work: The relationship between IT outsourcing vendors and clients is gradually shifted from simply an arm's length transaction in search of higher cost efficiency to global collaborative work [7,26]. The shift to strategic collaboration has elevated benefits of IT outsourcing beyond the limits of arms-length transaction strategy, and when implemented properly, provides both clients and vendors greater rewards than merely lower development costs [23]. However, proper implementation of effective collaboration is a challenging task, particularly for offshored projects, due to status differences and rigid boundaries that exist among organizations. Despite this challenge, effective collaborations have been achieved through open communication among participants attempting to freely share their viewpoints and "re-negotiate" boundaries and status differences [28, 32].

Relationship Management: IT outsourcing clients and vendors have come a long way in management of their outsourcing relationships. Lessons learned from the past outsourcing deals as well as the changes in outsourcing motivation, among other factors, have led to a noticeable maturity in, and effective management of, outsourcing relationship [48, 53]. Traditional approach to implementation of IT outsourcing deals has emphasized preparing a complete and comprehensive formal contract in order to minimize associated risks. While this view is still relevant and valid, formal contracts are more and more being complemented by unwritten inter-organizational exchanges that are conducive to building mutual trust and social identification [15,29]. Managing client and vendor relationship to enhance mutual trust and commitment have demonstrated positive impact on IT outsourcing success [41, 46].

Knowledge-Sharing: The early outsourcing practices mainly involved handing over routine and structured IT functions such as program coding to vendors to complete and deliver a job based on contractual terms and conditions-- a typical arm's length transaction. Recent outsourcing activities, on the other hand, encompass a considerable level of knowledge-sharing between clients and vendors [17, 30]. Knowledge-sharing strategy for IT outsourcing is more encompassing than mere exchange of information. Clients are not simply passive recipients of completed jobs; they proactively are involved in, and influence, all stages of design and development process [19]. Furthermore, IT outsourcing has become a possible and plausible way to integrate and enhance client-vendor knowledge. This perspective would help nurture the organizational learning capability [25]. Therefore, the shift to knowledge-sharing strategy implies a considerable change in IT outsourcing practice in terms developing and using knowledge management skills. To take advantage of the full benefits of knowledge-sharing, however, both service provider and service receiver must be ready and willing to collaborate to build a successful partnership in creating, sharing, and using knowledge [54]. 


\section{Issues in Information Systems}

Volume 13, Issue 2, pp. 146-154, 2012

Table 3: Changes in Client-Vendor Relationships

\begin{tabular}{|l|l|l|}
\hline \multicolumn{1}{|c|}{ Attribute } & \multicolumn{1}{|c|}{ Description } & \multicolumn{1}{|c|}{ Reference } \\
\hline $\begin{array}{l}\text { Move to Global } \\
\text { Collaboration }\end{array}$ & $\begin{array}{l}\text { The shift to strategic collaboration has increased the } \\
\text { benefits of IT outsourcing beyond the limits of arms- } \\
\text { length transaction strategy, providing both clients } \\
\text { and vendors greater rewards than merely lower } \\
\text { development costs. }\end{array}$ & $\begin{array}{l}\text { Cederlund } \text { et. al., 2007 } \\
\text { Koh, Ang, and Straub, 2004 } \\
\text { Levina and Vaast, 2008 }\end{array}$ \\
\hline $\begin{array}{l}\text { Relationship } \\
\text { Maturity }\end{array}$ & $\begin{array}{l}\text { Lessons learned from past deals have led to a } \\
\text { noticeable maturity in, and effective management of, } \\
\text { the outsourcing relationship. }\end{array}$ & $\begin{array}{l}\text { Solli-Sæether and Gottschalk, 2008 } \\
\text { Goo and Huang, 2008 } \\
\text { Sabherwal, 1999 }\end{array}$ \\
\hline $\begin{array}{l}\text { Knowledge- } \\
\text { Sharing }\end{array}$ & $\begin{array}{l}\text { The shift to outsourcing of knowledge-intensive } \\
\text { tasks, and knowledge-sharing strategy, implies a a } \\
\text { considerable change in IT outsourcing practice in in } \\
\text { terms developing and using knowledge management } \\
\text { skills. }\end{array}$ & $\begin{array}{l}\text { Gottschalk and Solli-Saether, 2005 } \\
\text { Grant, and Baden-Fuller, 2004 } \\
\text { Shi, et al, 2004 }\end{array}$ \\
Willcocks et al, 2004 \\
\hline
\end{tabular}

\section{SUMMARY AND CONCLUSION}

During the past three decades IT outsourcing has become an integral component of corporate strategy in today's organizations. Review of outsourcing literature indicates a number of noticeable shifts in IT outsourcing incentives and practices. It appears that although most of factors that have influenced the decision to outsource in the 80's and 90 's are still valid, there is a shift in the order of significance of some of these factors such as cost incentives. Also, new factors such as knowledge-sharing and strategic collaboration have received increased attention in various outsourcing decisions. Furthermore, a learning-curve phenomenon is effectively influencing changes in outsourcing practices. For the purpose of gaining a better understanding of the nature and direction of these changes, this "workin-progress" presents a preliminary literature review exploring major changes in some attributes of three dimensions of IT outsourcing: clients, vendors, and client-vendor relationships. Figure 1 shows various attributes of these outsourcing dimensions that have experienced some degree of changes. It may serve as a general framework for conducting future research to gain further understanding of the following areas:

1. The extent and direction of change in each specific dimension and its specific attributes.

2. Impact of changes in one attribute on other attributes of a particular dimension.

3. The ways that changes related to one dimension such as client may lead to changes regarding another dimension such as vendor. 


\section{Issues in Information Systems}

Volume 13, Issue 2, pp. 146-154, 2012

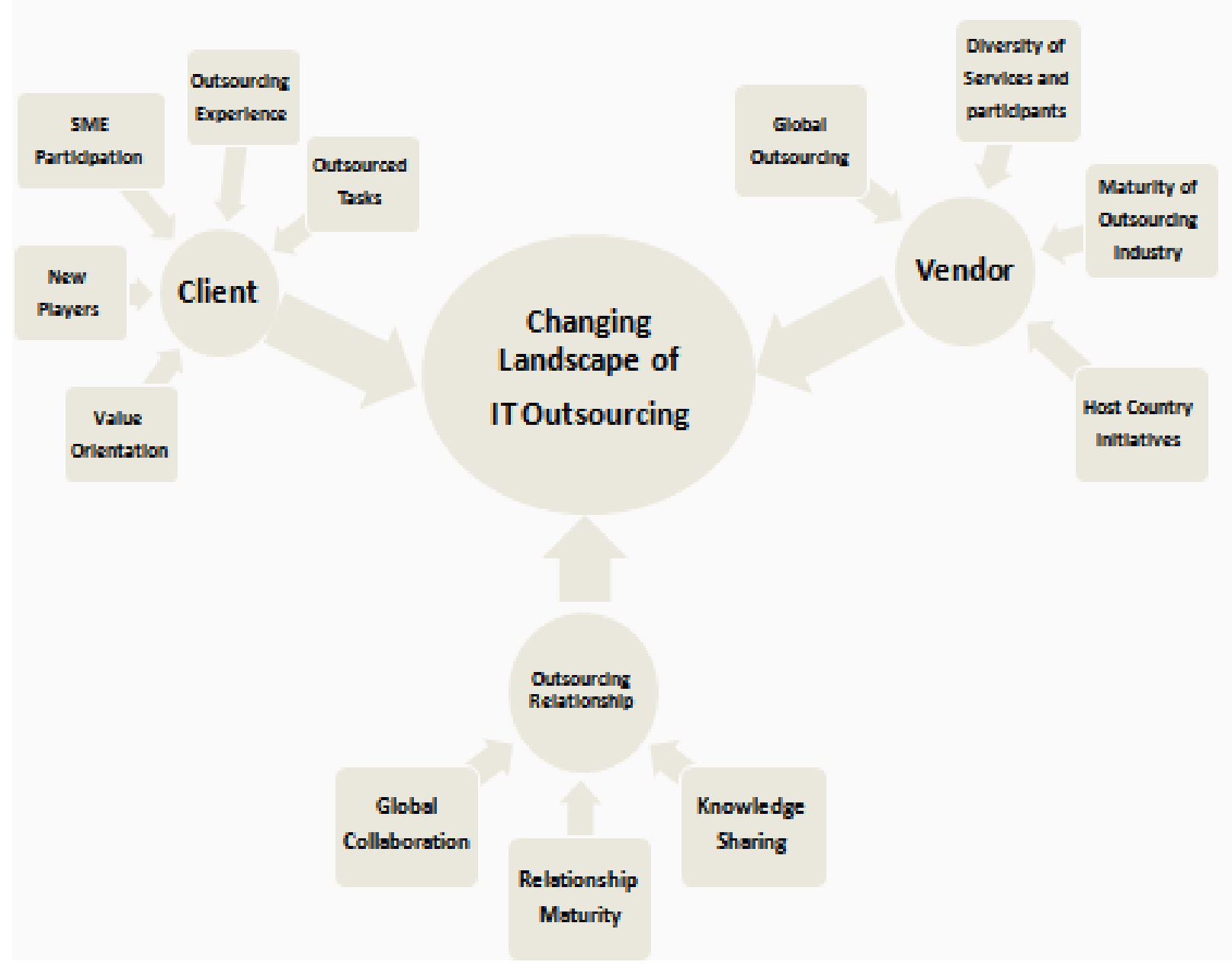

Figure 1: Changing Attributes of Three IT Outsourcing Dimensions.

\section{REFERENCES}

1. Babin, R., Briggs, S., \& Nicholson, B. (2011). Emerging Markets, Corporate Social Responsibility and Global IT Outsourcing. Communications of the ACM, 54(9), 28-30.

2. Barthelemy, J. (2001). The Hidden Costs of IT Outsourcing. MIT Sloan Management Review, 42(1), 60-69.

3. Borck, J. R. (2000). Selecting a Good ASP is Daunting, But If You Find the Right Factors, the Benefits are Great. InfoWorld, 23(12), 62.

4. Bryson, K.M. \& Sullivan, W.E. (2003). Designing effective incentive-oriented contracts for application service provider hosting of ERP systems. Business Process Management Journal, (9)6, 705-21.

5. Bullen, C.V., Abraham, T., Gallagher, K., Kaiser, K.M. \& Simon, J. (2007). Changing IT skills: the impact of sourcing strategies on in-house capability requirements. Journal of Electronic Commerce in Organizations, (5)2, 24-46. 


\section{Issues in Information Systems}

Volume 13, Issue 2, pp. 146-154, 2012

6. Carmel, E. \& Nicholson, B. (2005). Small firms and offshore software outsourcing: high transaction costs and their mitigation. Journal of Global Information Management, (13)3, 33-54.

7. Cederlund, J., Kauffman, R. J., Kohli, R., Markus, M. L., Melville, N. \& Pavlou, P. A. (2007). Global Sourcing of IT Services: Necessary Evil or Blessing in Disguise? Communications of AIS, 19 (1), 278-293.

8. Chu-Ping, L. \& Guang-Jong, F. (2010). Globalization strategy: foreign direct investment or international outsourcing trade? International Journal of Management \& Enterprise Development, 9 (2), 147-157.

9. Das, K. (2008). Select Issues and Debates around Geographical Indications with Particular Reference to India. Journal of World Trade, (42)3, 461-507.

10. Davies, P. (2004). What's this India Business? Offshoring, Outsourcing, and the Global Services Revolution. London: Nicholas Brealey International.

11. DePompa, B. (2003). Time to outsource ERP? Computerworld, (37)31, 33.

12. Dibbern, J., Winkler, J., \& Armin, H. (2008). Explaining Variations in Client Extra Costs between Software Projects Offshored to India. MIS Quarterly, (32)2, 333-366.

13. Fantasia, A. (2000). Decoding ASPs. Harvard Business Review, 78(6), 33-51.

14. Friedman, T. (2005). The World Is Flat: A Brief History of the Twenty-First Century. Farrar, Straus and Giroux, New York.

15. Goo, J. \& Huang, C. D. (2008). Facilitating relational governance through service level agreements in IT outsourcing: An application of the commitment-trust theory. Decision Support Systems, (46)1, 216-232.

16. Goo, J. \& Nam. (2007). Contract as a Source of Trust - Commitment in Successful IT Outsourcing Relationship: An Empirical Study. Proceedings of the 40th Hawaii International Conference on System Sciences.

17. Gottschalk, P. \& Solli-Saether, H. (2005). Critical Success Factors from IT Outsourcing Theories: An Empirical Study, Industrial Management \& Data Systems, 105(6), 685-702.

18. Gottschalk, P. \& Solli-Saether, H. (2006). Maturity Model for IT Outsourcing Relationships, Industrial Management \& Data Systems, 106(2), 200-212.

19. Grant, R. M. \& Baden-Fuller, C. (2004). A Knowledge Accessing Theory of Strategic Alliances, Journal of Management Studies, 41(1), 61-84.

20. Greenemeier, L. (2000). Aetna Expands Offshore outsourcing, InformationWeek, 17, 87.

21. Grimshaw, D. \& Miozzo, M. (2006). Institutional Effects on the IT Outsourcing Market: Analyzing Clients, Suppliers and Staff Transfer in Germany and the UK. Organization Studies, (27)9, 229-259.

22. Kenney, B. (2007). SaaS: Another Point Of Consideration. Industry Week, (256)5, 46.

23. Koh, C., Ang, S. \& Straub, D.W. (2004). IT outsourcing success: a psychological contract perspective. Information Systems Research, (15)4, 356-73.

24. King, J. (1999). Exporting jobs saves IT money. ComputerWorld, 33(11), 24.

25. Kolbasuk McGee, M. (2009). Outsourcing Bill Of Rights Proposed. InformationWeek, Available: http://www.informationweek.com/news/services/outsourcing/212902958

26. Kraft.com. (2006). Dinner by Design Home Meal Assembly Business Forms Agreement with Kraft Foods. http://www.kraft.com/newsroom/07182006.html.

27. Lacity, M. \& Willcocks, L. (1998). An Empirical Investigation of Information Technology Sourcing Practices: Lessons from Experience, MIS Quarterly, 22(3), 406-408.

28. Lavie, D. (2007). Alliance Portfolios and Firm Performance: A Study of Value Creation and Appropriation in the U.S. Software Industry. Strategic Management Journal, 28(12), 1187-1212.

29. Lee, J. N. \& Choi, B. (2011). Effects of initial and ongoing trust in IT outsourcing: A bilateral perspective, Information \& Management, 48(2/3), 96-105.

30. Lee, J. N. \& Kim, Y. G. (1999). Effect of Partnership Quality on IS Outsourcing Success: Conceptual Framework and Empirical Validation, Journal of Management Information System, 15(4), 29-62.

31. Lee, J. N. (2001). The Impact of Knowledge Sharing, Organizational Capability and Partnership Quality on IS Outsourcing Success. Information \& Management, 38(5), 323-335.

32. Levina, N. \& Vaast, E. (2008). Innovating or Doing As Told? Status Differences and Overlapping Boundaries in Offshore Collaboration. MIS Quarterly, (32)2, 307-332.

33. McFarlan, F. W. \& Delacey, B. (2004). Outsourcing IT: The Global Landscape in 2004. Harvard Business School Publishing, Article\# 9, 304-104. 


\section{Issues in Information Systems}

Volume 13, Issue 2, pp. 146-154, 2012

34. Mears, J. (2006). SMBs: outsourcing a growth tool. Network World, (23)8, 29.

35. Peslak, Alan R. (2012). Outsourcing and Offshore Outsourcing of Information Technology in Major Corporations. Management Research Review. 2012, (35)1, 14-31.

36. Popkin, J. M. \& Iyengar, P. (2007). IT and the East: How China and India Are Altering the Future of Technology and Innovation, Harvard Business School Press Books.

37. Pratt, M. K. (2006). Certified Outsourcing Professional. Computerworld, (40)39, 38-41.

38. Qu, W. G., Pinsonneault, A. \& Oh, W. (2011). Influence of Industry Characteristics on Information Technology Outsourcing. Journal of Management Information Systems, 27(4), 99-128.

39. Rashid, Amber Gul. (2012). Offshore Outsourcing of IT Services as New Service Development: The Role of Change and Its Management. Journal of Organizational Change Management, (25)3, 445-461.

40. Rustad, M. L. \& Koenig, T. H. (2007). Negligent Entrustment Liability for Outsourced Data. Journal of Internet Law, (10)10, 3-6.

41. Sabherwal, R. (1999). The Role Of Trust in Outsourced IS Development Projects. Communications of the ACM, (42)2, 80-86.

42. Schofield, S. (2008), The Evolution of Government Outsourcing Policy. Contract Management, 48(6), 54-61.

43. Schware, R. (2009), Give For-profit Rural Business Centers a Chance to Diversify Into Service-led Employment and Village BPOs. Information Technologies \& International Development, 5(2), 77-80.

44. Schwarz, A., Jayatilaka, B., Hirschheim, R. \& Goles, T. (2009). A Conjoint Approach to Understanding IT Application Services Outsourcing. Journal of the Association for Information Systems, 10(10), 748-781.

45. Shi, Z, Kunnathur, A.S., \& Ragu-Nathan, T.S. (2004). IS Outsourcing Management Competence Dimensions: Instrument Development and Relationship Exploration. Information \& Management, 42(2005), 901-919.

46. Sisk, M. (2003). State Street Finds Tech Allies to Keep its Forex Perch. Bank Technology News (16)1, 20.

47. Soat, J., (2004). IT Confidential: Offshore Outsourcing, Tax Dollars, Trouble. InformationWeek, Available: http://www.informationweek.com/news/ management/outsourcing/showArticle.jhtml?articleID=55301201.

48. Solli-Sæether, H. \& Gottschalk, P. (2008). Maturity in IT outsourcing relationships: an exploratory study of client companies. Industrial Management \& Data Systems, (108)5, 635-649.

49. Susarla, A., Barua, A., \& Whinston, A. B. (2003). Understanding the Service Component of Application Service Provision: An Empirical Analysis of Satisfaction with ASP Services. MIS Quarterly, (27)1, 92-123.

50. Tafti, M. (2005). Risks Factors Associated with Offshore IT Outsourcing. Industrial Management \& Data Systems, 104(5), 549-560.

51. Thibodeau, P. (2006). Update: San Diego OKs \$667M outsourcing deal. ComputerWorld, Available: http://www.computerworld.com/managementtopics/ outsourcing/story/0,10801,108019,00.html?source=NLT_PM\&nid=108019, Last site visit: January 23, 2009.

52. Vijayan, J. (2004). Offshore outsourcing poses privacy perils. ComputerWorld, (38)8, 10.

53. Whitaker, J., Mithas, S. \& Krishnan, M. (2010). Organizational Learning and Capabilities for Onshore and Offshore Business Process Outsourcing. Journal of Management Information Systems, 27(3), 11-42.

54. Willcocks, L., Hindle. J., Feeny, D. \& Lacity, M. (2004). IT and Business Process Outsourcing: The Knowledge Potential. Information Systems Management, (21)3, 7-15. 